\title{
Biological Treatment of a Textile Effluent After Electrochemical Oxidation of Reactive Dyes
}

\author{
Mercè Vilaseca ${ }^{1}$, Maria-Carmen Gutiérrez ${ }^{1 *}$, Victor López-Grimau², Montserrat López-Mesas ${ }^{3}$, \\ Martí Crespi ${ }^{1}$
}

\begin{abstract}
In this work, a synthetic textile effluent containing a reactive dye (C.I. Reactive Orange 4) was treated in an electrochemical cell with titanium covered by platinum oxide $\left(\mathrm{Ti} / \mathrm{PtO}_{\mathrm{x}}\right)$ electrodes to remove color. The discolored effluent was mixed with other textile mill process effluents (scouring, bleaching, washing, etc.), according to the rate of each effluent in the mill, and was submitted to biological treatment (activated sludge plant).

Two biological plants were run simultaneously to evaluate the influence of oxidant products generated during the electrochemical treatment. The final chemical oxygen demand (COD) removal in both plants was 65 to $72 \%$. The yield of the activated sludge plants was not affected by the addition of $10 \%$ of the discolored dyeing effluent (even when oxidants products were not removed), which indicates that the previous electrochemical treatment do not produce inhibition effects on the biological plant. However, in the case of direct addition of the discolored effluent, the biological treatment plant required a longer adaptation period.

In addition, the electrolytic respirometry tests showed that all the biodegradable organic matter was removed, which implies that the yield in organic matter removal was the maximum possible for this type of treatment. Water Environ. Res., 82, 176 (2010).
\end{abstract}

KEYWORDS: biodegradability, respirometry, reactive dyes, wastewater, electrochemical treatment, oxidation-reduction, color removal, biological treatment.

doi: $10.2175 / 106143009$ X447902

\section{Introduction}

The textile industry is characterized by the large volume and variability of the wastewater generated, with dyeing processes and finishing operations producing the largest amounts of wastewater. This type of effluent typically contains byproducts, residual dyes, and auxiliary chemicals. In general, textile industry wastewaters are colored, highly alkaline, and high in biochemical oxygen

\footnotetext{
${ }^{1}$ INTEXTER, Institute of Textile Research, Technical University of Catalonia, Terrassa, Spain.

${ }^{2}$ Department of Project Engineering, School of Industrial and Aeronautics Engineering (ETSEIAT), Technical University of Catalonia, Terrassa, Spain.

${ }^{3}$ Analytical Chemistry Unit, Department of Chemistry, Faculty of Science, Autonomous University of Barcelona, Bellaterra, Spain.

* INTEXTER, Institute of Textile Research, Technical University of Catalonia, Colom 15, 08222 Terrassa, Spain; e-mail: gutierrez@intexter. upc.edu.
}

demand (BOD), suspended solids, and temperature (Mohan et al., 2007; U.S. EPA, 1997).

As it is well-known, biological treatment by activated sludge is the most used treatment for municipal and industrial wastewaters. However, biological treatment generally is insufficient to remove the wastewater color. Some types of textile dyes, mainly reactive ones, are only partially removed by adsorption in the sludge, as they have a very low degradation ratio. To comply with current regulations, the application of specific treatments is required.

To achieve a marked color reduction after a biological process, a further application of relatively expensive tertiary treatments is required, typically performed by techniques such as adsorption with active carbon (Malik, 2004), membrane filtration (Jhawar et al., 2003; Koyuncu, 2002), ozonation (Koch et al., 2002; Zhao et al., 2004), coagulation-flocculation (Allegre et al., 2004; Golob et al., 2005), photocatalytic degradation (Arslan-Alaton et al., 2002; Torrades et al., 2004), and electrochemical techniques (Chen et al., 2003; Kim et al., 2002, 2003; Sakakibara and Nakayama, 2001).

In the past few years, the use of electrochemical techniques for industrial effluent treatment has increased quickly. Electrochemical techniques are based on effluent electrolysis. Such processes are clean, operate at low temperatures, and, in most cases, do not require the addition of reagents. This is the case of the textile effluents containing reactive dyes, where the required electrolyte is already present in the solution. In the past few years, the total or partial destruction of organic compounds in effluents by electrochemical treatment is achieved by oxidation, which can occur directly at the anode and/or indirectly by species generated by the anode (Gutierrez et al., 2002); however, a reduction also can occur simultaneously, as the anode and cathode are not separated.

On the basis of our previous studies (Lopez-Grimau and Gutierrez, 2006), in this work, electrochemical treatment is proposed to remove the color of dyeing effluents before they are treated with the remaining wastewater in the biological plant. Although, currently in the industry, the residual color is removed after the biological treatment, in this study, a color-removal step before the biological treatment is carried out. The effluents generated in dyeing processes (generally $10 \%$ of the global textile wastewater) were segregated to previously remove color. In this process, the large reactive dye molecules are broken into smaller, uncolored, and more biodegradable species. Once discolored, these effluents are incorporated to the biological treatment plant to obtain a further degradation. 
In the present work, a synthetic effluent containing a reactive dye was treated in an electrochemical cell with titanium covered by platinum oxide $\left(\mathrm{Ti} / \mathrm{PtO}_{\mathrm{x}}\right)$ electrodes, to remove color. This type of effluent contains chloride ions, which are partially converted by the treatment into chlorine or hypochlorite by oxidation in the anode. The main objective of this work was to evaluate how the presence of these electrochemically generated species influenced the biological treatment yield.

The discolored effluent was mixed after the electrochemical treatment with other textile mill process effluents coming from different textile processes, such as scouring, bleaching, and washing. They were mixed according to the rate of each effluent in the mill and submitted to biological treatment by the activated sludge plant. The yield to remove the organic matter was evaluated.

\section{Material and Methods}

Preparation of the Synthetic Wastewater. The plants were feed with synthetic wastewater prepared to simulate a representative textile mill effluent (ME) produced during cotton dyeing processes in textile mills. The mill effluent was prepared weekly in the amount required to feed the biological plants. It was prepared from a mixture of three effluents belonging to different textile industrial processes, as follows:

- Effluent 1 was prepared by mixing three surfactants and two sizing agents. The surfactants, supplied by different companies, were as follow: $0.05 \mathrm{~g} / \mathrm{L}$ of Findet $1618 \mathrm{~A} / 72-\mathrm{E}$ (KAO Corporation [Barberà del Vallès, Spain], fatty alcohol dispersing agent); $0.007 \mathrm{~g} / \mathrm{L}$ of Tetranil AHT-1 (KAO Corporation, fabric softener agent); and $0.1 \mathrm{~g} / \mathrm{L}$ of Amplex CA-ECO (Color-Center [Terrassa, Spain], anionic polycarboxylate surfactant). The sizing agents were $0.1 \mathrm{~g} / \mathrm{L}$ starch and $0.2 \mathrm{~g} / \mathrm{L}$ polyvinyl alcohol (Merck Company, Mollet del Vallès, Spain). This synthetic effluent simulated a mixture of a washing, soaping, and softening wastewater at a rate of 40 , 30 and $10 \%$, respectively, according to the rate of each process in the mill.

- Effluent 2 was a synthetic dyeing effluent prepared at the laboratory with an azo/dichlorotriazine reactive dye (C.I. Reactive Orange 4, Procion MX-2R) supplied by Dystar (L'Hospitalet de Llobregat, Spain).

To simulate the experimental conditions of the industrial effluents, the dye $(0.1 \mathrm{~g} / \mathrm{L})$ might be hydrolyzed, which was accomplished by heating the solution under alkaline conditions ( $\mathrm{pH} 12$ with $1 \mathrm{M}$ sodium hydroxide, at $100^{\circ} \mathrm{C}$, for 1 hour). Once the hydrolysis was completed, the most typical parameters of the residual reactive dyeing liquors were established; the final $\mathrm{pH}$ was adjusted to 9 with $1 \mathrm{M}$ hydrochlorice acid, and the conductivity was fixed at $35 \mathrm{mS} /$ $\mathrm{cm}$ by adding sodium chloride. This effluent was treated in an electrochemical cell to remove color before the mixing step of effluents 1,2, and 3 (see next section for further description).

After the electrochemical treatment, effluent 2 had color concentration of $3500 \mathrm{mg} \mathrm{Pt}-\mathrm{Co} / \mathrm{L}$ (APHA et al., 1998), a COD of $59 \mathrm{mg} / \mathrm{L}$, and a total organic carbon (TOC) of $32 \mathrm{mg} / \mathrm{L}$. After the treatment, the color was removed completely, and COD and TOC diminished to 46 and $26 \mathrm{mg} / \mathrm{L}$, respectively. A chlorine concentration of $600 \mathrm{mg} / \mathrm{L}$ was generated.

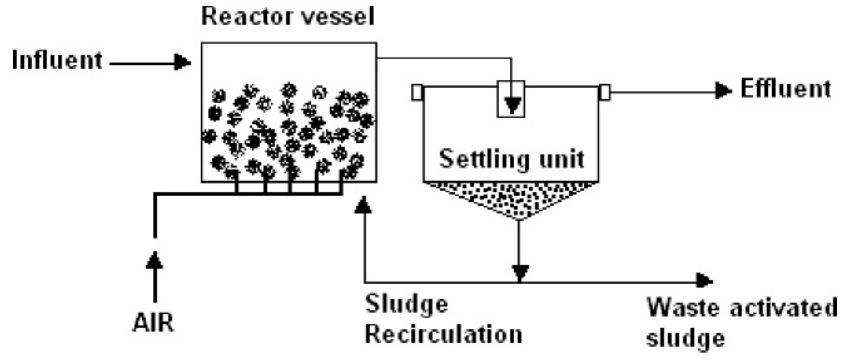

Figure 1-Scheme of the biological treatment plants.

- Effluent 3 was an industrial effluent that was collected directly from a Spanish cotton processing mill (Tintes Viscolan, S.A., TIVISA, Terrassa, Spain), which contained grease and other compounds extracted from the fiber during the initial cleaning step (scouring). This effluent cannot be simulated in a laboratory because of its complexity and because its composition may vary, depending on the kind and origin of the scoured fiber. The average of COD was 13 $000 \mathrm{mg} / \mathrm{L}$, the total suspended solids (TSS) was $425 \mathrm{mg} / \mathrm{L}$, the grease concentration was $530 \mathrm{mg} / \mathrm{L}$, the $\mathrm{pH}$ value was 11 , and the conductivity reached $7 \mathrm{mS} / \mathrm{cm}$.

The rate of each effluent in the mixture was as follows: $80 \%$ of effluent 1, 10\% of effluent 2, and $10 \%$ of effluent 3 . The simulated dyeing effluent (or effluent 2) was not mixed directly with the rest of process effluents (effluents 1 and 3) because the residual hydrolyzed reactive dye, which is still highly colored, is not removed by the biological treatment, but requires an additional treatment.

Treatment of the Dyeing Effluent (Effluent 2) to Remove Color. For this purpose, electrochemical treatment was the selected technique. It was carried out in an ECO 75 cell (ELCHEM, Freigericht-Somborn, Germany). Although the electrochemical technique almost can achieve mineralization of the dyes, in this work, they were not mineralized to avoid excessive energy consumption, to make this process competitive for the textile industry (Lopez-Grimau and Gutierrez, 2006). Consequently, during the electrochemical treatment, the dye molecules were broken only partially.

As optimized in a previous work (Lopez-Grimau and Gutierrez, 2006), the experimental conditions were set at $6 \mathrm{~mA} / \mathrm{cm}^{2}$ for the current density and $25 \mathrm{~L} / \mathrm{h}$ for the dye solution flowrate. Under these conditions, a decolorization of $72 \%$ was obtained immediately after the treatment, and the full decolorization was obtained after storage of the treated effluent under solar light; to date, this procedure has not been used at the textile industry.

The color of treated and untreated solutions was evaluated measuring the absorbance at the maximum of absorption of the dye $(488 \mathrm{~nm})$.

The amount of chlorine/hypochlorite generated after the treatment, resulting from the presence of chloride ion in the effluent, was analyzed by a test kit (Chemets Kit Chlorine K2502, CHEMetrics Inc., Calverton, Virginia).

To evaluate the influence of chlorine/hypochlorite on the biological treatment, they were removed in one part of the discolored effluent 2 by adding a stoichiometric amount of sodium bisulfite followed by aeration for 2 hours. In this way, two types of effluent 2 were obtained $(\mathrm{A}=$ free of chlorine, and $\mathrm{B}=$ without removal of chlorine). 
a)

Electrochemical treated dyeing effluent

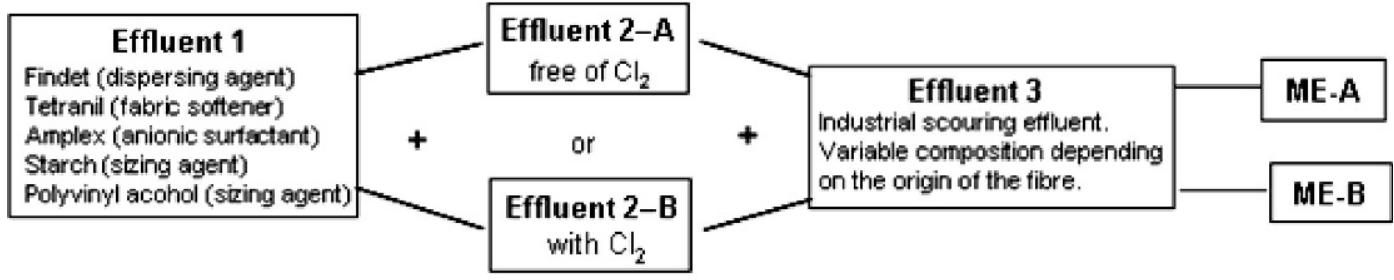

$80 \%$

$10 \%$

$10 \%$

b)

\begin{tabular}{|c|c|}
\hline ME-A1 & $\begin{array}{c}\text { ME-B1 } \\
\text { free of } \mathrm{Cl}_{2}\end{array}$ \\
with $\mathrm{Cl}_{2}$ \\
HRT 6.0
\end{tabular}$\quad$\begin{tabular}{l} 
HRT 6.0 \\
\hline
\end{tabular}

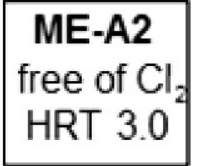

ME-B2
with $\mathrm{Cl}_{2}$
HRT 3.0

Figure 2-(a) Scheme of the different mill effluents prepared to feed the plants, and (b) scheme of the experimental conditions for the four biological pilot plants.

Biological Treatment. The biological activated sludge treatment was carried out in four laboratory pilot plants, with a capacity of $5 \mathrm{~L}$, provided with aerobic reactor vessels and with a settling unit, which operated continuously (see scheme in Figure 1).

The $\mathrm{pH}$ of the feeding effluents was adjusted in the range 6.5 to 7.5 with concentrated sulfuric acid. The biological pilot plants were inoculated with activated sludge from an urban wastewater treatment plant.

Figure 2 shows the scheme of preparation of the mill effluents, as discussed above. The effect of the presence of chlorine was evaluated, as can be seen in Figure 2a, by feeding the plants with two different mill effluents (ME-A = free of chlorine, and ME-B $=$ without removal of chlorine).

In addition, for each effluent, two types of experiments were run by adjusting two different feeding rates (Figure 2b), which corresponds to a hydraulic retention time (HRT) of 6 days (plant 1) and 3 days (plant 2).

Thus, the study was carried out on four plants - two for plant 1 (ME-A1 and ME-B1, without and with chloride, respectively), and two for plant 2 (plants ME-A2 and ME-B2, without and with chloride, respectively). All biological pilot plants were evaluated during 33 days.

Analytical Methods for the Wastewater Characterization. To follow the evolution of the biological plants, the following influent and effluent parameters were evaluated regularly: COD (AENOR, 2002), conductivity (APHA et al., 1998), chlorine (CHEMetris K-2505, CHEMetrics Inc.), mixed liquor suspended solids (MLSS), and TSS (AENOR, 2006).

The respirometric biodegradability (BOD) also was evaluated by the use of an electrolytic respirometer BI-1000 (Bioscience Inc., Allentown, Pennsylvania). Respirometry is the measurement of the respiration of microorganisms. Aerobic respiration is the energy production mechanism for most microorganisms. It commonly involves consumption of oxygen and release of carbon dioxide (Zitrides et al., 2006). The electrolytic respirometer provides a direct and continuous measurement of oxygen consumption in samples of water, wastewater, polluted soils, residual liquids, and solutions of chemical compounds. Electrolytic respirometers typically are used in treatment plants for municipal and industrial pollution control and to determine the biodegradability and toxicity of industrial wastewater. Respirometry is based on the measurement and the interpretation of the dissolved oxygen uptake rate by microorganisms in a reactor. The accumulated oxygen uptake (AOU) versus time has been the most widely used for various applications, including kinetic estimation, respirometric BOD, and toxicity assessment.

The respirometric tests were carried out during at least 5 days at $20^{\circ} \mathrm{C}$. For each experiment, a blank test, with distilled water, also was registered. The same nutrient solutions as for the BOD test

Table 1-Average results of the biological pilot plant studies.

\begin{tabular}{|c|c|c|c|c|c|c|c|c|c|}
\hline Effluents & $\begin{array}{c}\text { COD } \\
(\mathrm{mg} / \mathrm{L})\end{array}$ & $\begin{array}{c}\text { COD } \\
\text { removal (\%) }\end{array}$ & $\begin{array}{c}\text { TSS } \\
(\mathrm{mg} / \mathrm{L})\end{array}$ & $\begin{array}{c}\text { MLSS } \\
(g / L)\end{array}$ & $\begin{array}{c}\text { Conductivity } \\
\text { S/cm }\end{array}$ & $\mathrm{pH}$ & $\begin{array}{c}Q \\
(\mathrm{~L} / \mathrm{d})\end{array}$ & $\mathrm{F} / \mathrm{M}$ & $\begin{array}{c}\text { Chlorine } \\
\text { (mg/L) }\end{array}$ \\
\hline ME-A1 IN & 1176 & & 67.4 & & 6.04 & 7.4 & & & - \\
\hline ME-A1 OUT & 424 & 64.8 & 23.8 & 1.1 & 6.41 & 8.1 & 0.78 & 0.22 & - \\
\hline ME-B1 IN & 1201 & & 79.5 & & 5.89 & 7.5 & & & 6 \\
\hline ME-B1 OUT & 332 & 72.4 & 48.5 & 1.4 & 6.17 & 8.1 & 0.79 & 0.24 & 0,8 \\
\hline ME-A2 IN & 2040 & & 195.6 & & 6.66 & 6.8 & & & - \\
\hline ME-A2 OUT & 718 & 65.3 & 137.6 & 1.9 & 6.57 & 8.1 & 1.63 & 0.33 & - \\
\hline ME-B2 IN & 2788 & & 157.2 & & 6.19 & 6.9 & & & 48 \\
\hline ME-B2 OUT & 866 & 64.9 & 232.4 & 2.1 & 5.9 & 8.2 & 1.74 & 0.46 & 7 \\
\hline
\end{tabular}




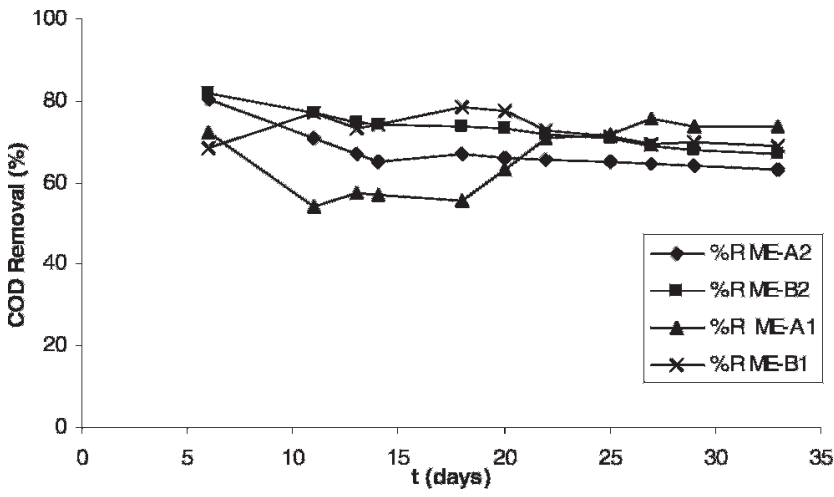

Figure 3-Evolution of COD removal for the four biological plants.

were added (APHA et al., 1998). The $\mathrm{pH}$ was verified and adjusted, if necessary, to between 7 and 7.5. The samples and blanks were inoculated with activated sludge (30 mg MLSSL/L sample) taken from the corresponding pilot plants just before starting the respirometry or with BOD inoculums, if the sludge still was not adapted.

Microscopic Observation. Samples of $50 \mathrm{~mL}$ of sludge were taken from the reactor and were homogenized to carry out microscopic observations. The observations were performed weekly with an optical microscope (Olympus BH-2, Tokyo, Japan) at magnifications of $40 \times, 100 \times$, and $400 \times$.

\section{Results and Discussion}

Organic Matter Removal. The mean physicochemical parameters evaluated for the different mill effluents are shown in Table 1. The different influents (ME-IN) presented a wide range of values, showing the complexity of this type of effluent. This is because of the variability of industrial effluent 3 , as it was collected on different days.

Figure 3 shows the evolution of the COD removal for the four biological plants evaluated. Comparing plants ME-A1 and ME$\mathrm{B} 1$, the organic matter removal seemed to be better for the second one during the first 10 days of the study, although chlorine, which is considered to be an inhibitory factor for microorganisms, was not removed. This contradictory behavior was attributed to a punctual trouble found in the feeding flowrate of ME-A1; it was detected that, during a few days, an excess of influent was supplied to the biological plant, and the microorganisms were not able to degrade all the organic material, causing the lower COD removal yield in this pilot plant. Once the problem with the pump was solved, the COD removal increased, until the value for both plant ME-B1 samples was similar at the end of the study. For the second batch of plants (ME-A2 and ME-B2), the same final result was obtained.

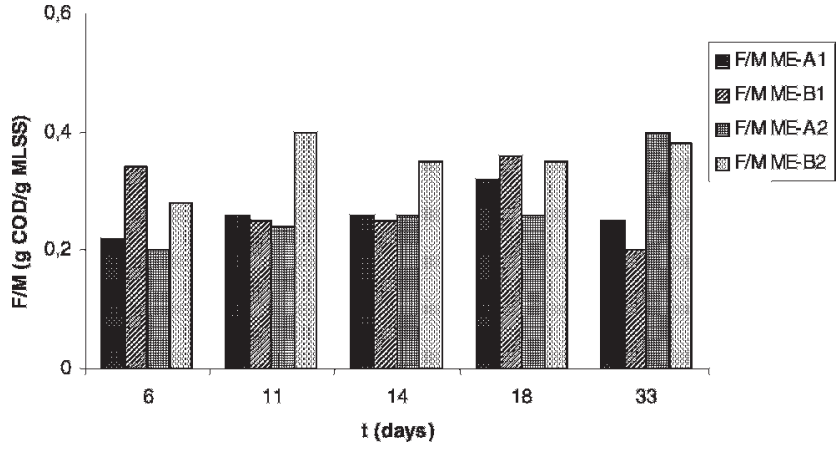

Figure 4-Evolution of $\mathrm{F} / \mathrm{M}$ in the different plants.

These results indicate that the residual chlorine contained in the $\mathrm{B}$ effluents, produced during the electrochemical decolorization of the dyeing wastewater, did not have any significant influence on the biological treatment efficiency.

The operational parameters of the different experiments carried out with the two biological pilot plants are presented in Table 2. The solids retention time (SRT), food-to-microorganism ratio $(\mathrm{F} /$ $\mathrm{M})$, dissolved oxygen concentration, volumetric loading rate, and HRT were calculated as typical design parameters for commonly used activated sludge processes (Metcalf \& Eddy, 2003). From the results shown in Table 2, it can be said that the plants of the second experiment (ME-A2 and ME-B2) present typical values corresponding to complete-mix processes. However, the operational parameters of plants ME-A1 and ME-B1, where the HRT was doubled, are closer to an extended aeration process.

The F/M ratio is an indication of the good performance of the biological plants. The F/M values were used to control the process, because the sludge was never purged, as its production was very low. As shown in Figure 4, the ratio of F/M varied from 0.15 to $0.45 \mathrm{~g} \mathrm{COD} / \mathrm{g} \mathrm{MLSS} / \mathrm{d}$, during the operation time (the ratio MLVSS/MLSS was 0.8). These results are according to the literature (Metcalf \& Eddy, 2003), which indicates that, for industrial wastewaters containing compounds with low biodegradability, F/M ratio is found in the range 0.15 to 0.4 .

Comparing the effects of chlorine in the biological plants, it was observed that the difference of $\mathrm{F} / \mathrm{M}$ ratio between pilot plant $\mathrm{A} 1$ and $\mathrm{B} 1$ was not significant (HRT $=6$ days). For the experiments carried out at a 3-day HRT, the F/M value for B2 was higher than $\mathrm{A} 2$, as a result of the higher COD of the influent (as indicated in Table 1)

Microscopic Observation. Biological analysis of activated sludge enable the state of active biomass to be known and to fit the parameters of control in the plant, to obtain an effective operation and a good maintenance of the system (Vilaseca, 2001).

According to the microscopic observations of the sludge during the study, there were no significant differences between the

Table 2-Operational parameters of the two experiments carried out with the two biological pilot plants.

\begin{tabular}{|c|c|c|c|c|}
\hline Parameter & ME-A1 & ME-B1 & ME-A2 & ME-B2 \\
\hline SRT (days) & 47.1 & 28.7 & 13.9 & 8.8 \\
\hline F/M (g COD/g MLSS·d) & 0.22 & 0.24 & 0.33 & 0.46 \\
\hline Dissolved oxygen $\left(\mathrm{mg} \mathrm{O}_{2} / \mathrm{L}\right)$ & 2 & 2 & 2 & 2 \\
\hline Volumetric loading $\left(\mathrm{kg} \mathrm{COD} / \mathrm{m}^{3} \cdot \mathrm{d}\right)$ & 0.19 & 0.19 & 0.68 & 0.85 \\
\hline HRT (days) & 6 & 6 & 3 & 3 \\
\hline
\end{tabular}




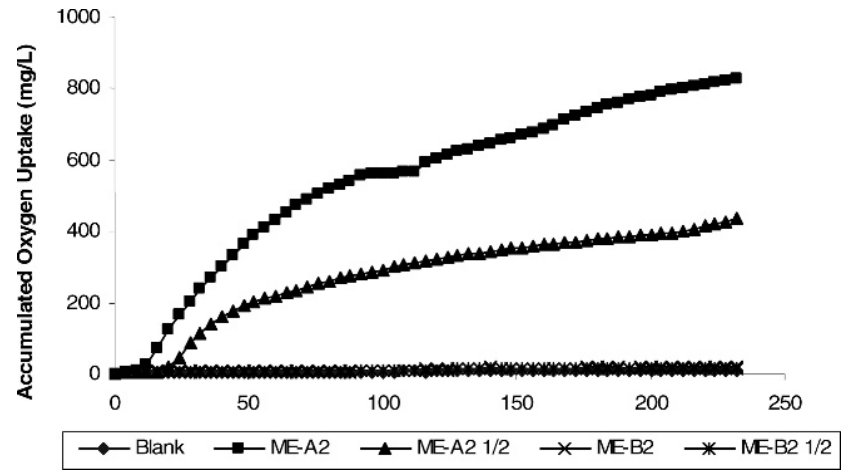

Figure 5-Respirometries of the influents ME-A2 and MEB2 with unadapted inoculum.

microorganisms found in the four different plants. This indicates that the chlorine contained in influents ME-B1 and ME-B2 did not cause an observable effect on the microorganisms. The evolution of the microorganisms in the different plants studied was as expected. From the starting of the plants up to their stabilization, the normal succession of microorganisms was found. In an initial phase, there was abundance of disperse bacteria, flagellated, and small ciliated swimmers, such as as Colpidium and Blepharisme, which were indicators of a strong charge average. Ten days after startup of the plants, the growth of flocks implied the substitution of disperse bacteria and flagellated protozoas by ciliates of bigger size, such as Paramecium and Litonotus, and crawler ciliates, such as Aspidisca and Euplotes, which indicated a good state of depuration. Also, the presence of stalked ciliates, such as Opercularia sp. and Vorticellas, was observed as an indicator of good performance. After 4 weeks of study, some nematodes, actinopodas, rotifers, and mites appeared in the sludge.

Respirometric Study. An electrolytic respirometric study was carried out to evaluate the biodegradability and presence of toxic compounds in wastewater samples. This technique provides a direct and continuous measurement of the oxygen uptake, as a result of the activity of microorganisms. Two types of inoculum were used to evaluate the degradation of the organic matter in the influents-unadapted (the same as used for 5-day BOD experiments) and adapted (activated sludge from plants ME-B1 and MEB2).

For the unadapted inoculums, the results of the respirometric studies are shown in Figure 5. The study was performed with the influents and their $1 / 2$ dilution, to determine a possible inhibition or toxicity effect. As can be observed, the influent ME-A2 did not exhibit any inhibitory effects and showed a high biodegradability level. This is not the case of influent ME-B2, because the

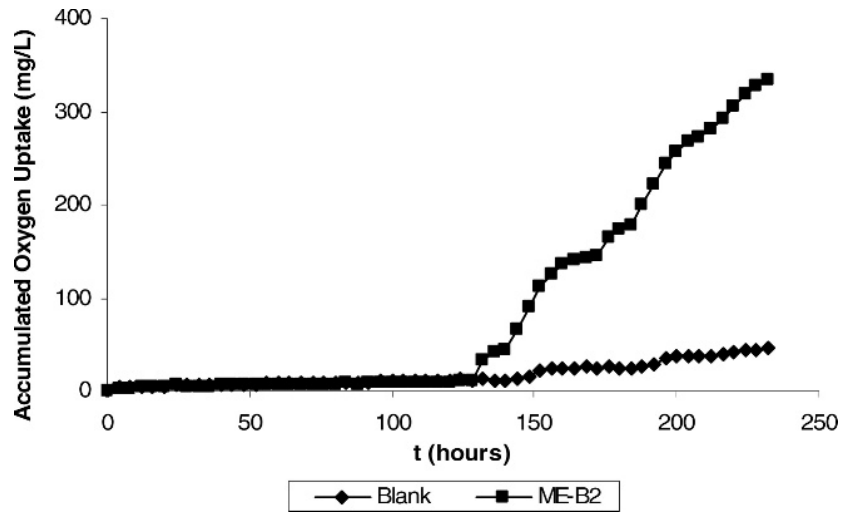

Figure 6-Effect of inoculum adaptation on respirometric curves for the chlorine containing influent (ME-B2).

adaptation of the microorganisms was not possible, as a result of the presence of chlorine.

The inhibitory effects can be evaluated in more detail in Table 3. For the influents where the chlorine had been removed previously (e.g., ME-A2), the relation found between COD and BOD shows values consistent with biodegradable effluent. However, for the influents with chlorine (e.g., ME-B2), the high ratio was representative of non-biodegradable effluents, as a result of the inhibitory effect of chlorine over microorganisms.

The ratio of COD to BOD of ME-A2 shown in Table 3 was found to be similar (2.5 and 2.4) when a dilution of the sample was performed, which indicates a high effluent biodegradability. On the other hand, for the chlorine containing influent ME-B2, a total inhibition of the microorganism activity was observed during the 232 hours of the respirometric study (Figure 5). A COD/BOD ratio of 249 corresponds to a non-biodegradable influent.

When the respirometric tests were carried out with an adapted inoculum (sludge from plant ME-B2), the respiration rate was inhibited only at the beginning, for the chlorine containing influent. After a period of 128 hours, which was needed for adaptation of the microorganisms, the rate increased, with respect to the blank and to the sample with unadapted inoculum, as shown in Figure 6. This behavior indicates that a certain adaptation period was required when the effluent contained a residual amount of chlorine, but the biodegradation also was possible with this kind of inoculum. After this adaptation period, the wastewater can be submitted to a biological treatment, as the COD/BOD ratio at 232 hours was 8.6 (Table 2).

Despite these respirometric results, the yields of the biological treatments were within the expected range, but the values exhibited were not high, what indicates that all organic matter

Table 3-Respirometric parameters for the different influents.

\begin{tabular}{|c|c|c|c|c|c|}
\hline \multicolumn{6}{|c|}{$t=232$ hours } \\
\hline Sample (influents) & COD (mg/L) & Dilution & Inoculum & AOU (mg/L) & COD/BOD \\
\hline \multirow[t]{2}{*}{ ME-A2 } & 2040 & - & No Adapted & 818 & 2.5 \\
\hline & & $1 / 2$ & & 426 & 2.4 \\
\hline \multirow[t]{2}{*}{ ME-B2 } & 2488 & - & No Adapted & 10 & 249 \\
\hline & & $1 / 2$ & & 5 & 249 \\
\hline ME-B2 & 2488 & - & Adapted & 289 & 8.6 \\
\hline
\end{tabular}




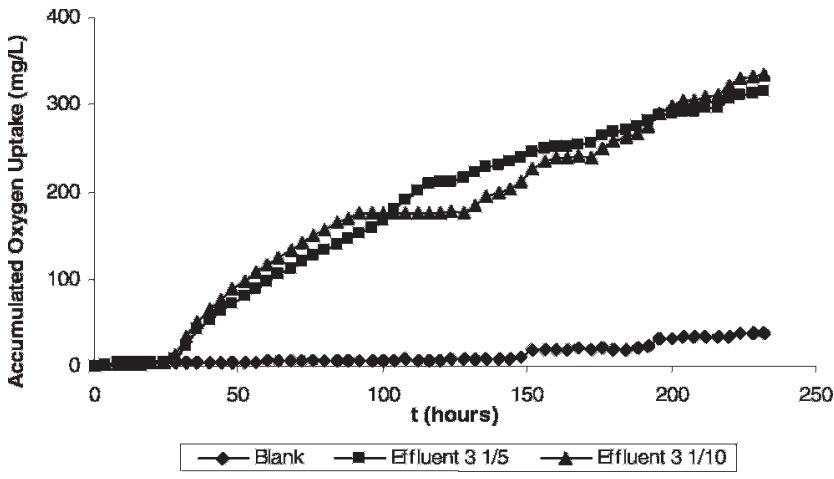

Figure 7-Respirometric study of the industrial scouring effluent (effluent 3).

in the wastewater cannot be degraded biologically. This can be attributed to the presence of recalcitrant compounds in the wastewater, which are introduced through the industrial scouring process effluent (effluent 3 ). This hypothesis was confirmed by an electrolytic respirometric test. As shown in Figure 7, the two different dilutions carried out for the effluent 3 (1/5 and 1/10) showed the toxic effect of this effluent, as no differences in the final oxygen uptake amount were found.

Consequently, to reach a higher organic matter removal ratio, this type of textile industry wastewater would require another supporting treatment (i.e., a physico-chemical or membrane bioreactor). In this sense, respirometries of influents (IN) and effluents (OUT) of the biological plants are compared in Figure 8. The figure shows that, after the biological treatment, the respiration ratio was similar to the blank, which indicates that the biodegradable fraction of the wastewater already was fully degraded, and only the recalcitrant compounds remained as residual organic matter.

In summary, the reactive dye wastewater can be treated by means of an electrochemical process to remove color, and the discolored effluent can be submitted directly to a biological treatment with the rest of the textile process effluents. It was not necessary to previously remove the residual chlorine, as its presence in the discolored effluent did not affect the yield of the biological treatment. The only difference was that a longer adaptation of the sludge, in the case of chlorine-containing effluents, was required at the start of the biological treatment. In all cases, the conventional activated sludge process provided COD removal values between 65 and $72 \%$. The electrolytic respirometry technique allowed us to confirm that the removal of biodegradable organic matter with the biological treatment reached the best yield possible for these types of compounds, because the degradable organic matter of the effluent (OUT) was removed completely, as shown in Figure 8.

The organic matter remaining in the effluent corresponded to non-biodegradable compounds, which must be removed by using a tertiary treatment, which is consistent with results found in the literature (Bankian and Merhrvar, 2004; Rajkumar and Guk-Kim, 2006; Vidal et al., 2004). In such cases, biological processes alone are not able to reach effluent standards for the discharge to a municipal sewer or surface water; therefore, a pretreatment or post-treatment is required. We propose that an appropriate way to increase the yield of the biological plants could be to mix the

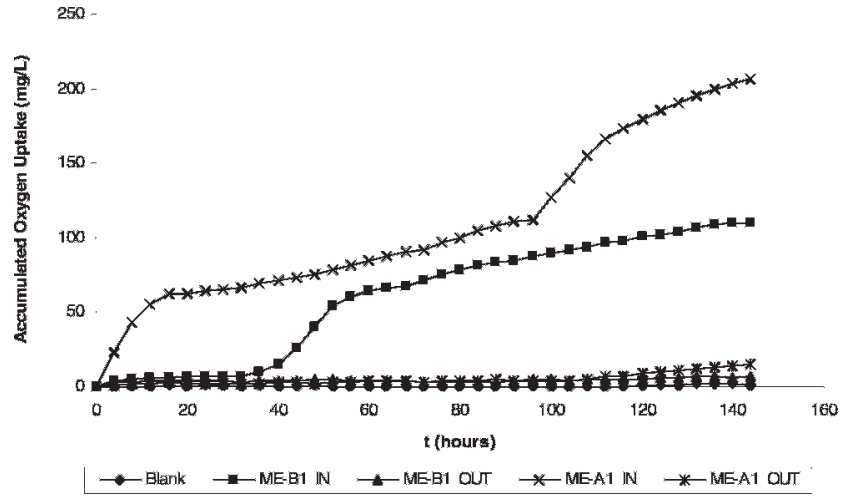

Figure 8-Respirometry of influent and effluent of the biological plants (experiment 1 ).

scouring recalcitrant effluent with the dyeing effluent (in this work, effluents 3 and 1, respectively) to perform an electrochemical oxidation process of the combined effluent before the biological treatment.

\section{Credits}

This work was supported by the Spanish Ministry of Education (Madrid) (projects CTM2004-05774-C02-01/TECNO and CTM2007-66570-C02-01/TECNO).

Submitted for publication September 9, 2008; revised manuscript submitted June 18, 2009; accepted for publication July 16 , 2009.

\section{References}

AENOR, Spanish Association for Standardization and Certification (2002) Determination of the Chemical Oxygen Demand (COD). Dichromate Method. UNE 77004:2002, Madrid, Spain.

AENOR, Spanish Association for Standardization and Certification (2006) Determination of Suspended Solids. Method by Filtration Through Glass Fiber Filters. UNE-EN 872:2006, Madrid, Spain.

Allegre, C.; Maisseu, M.; Charbit, F.; Moulin, P. (2004) CoagulationFlocculation-Decantation of Dye House Effluents: Concentrated Effluents. J. Hazard. Mater., B116, 57-64.

American Public Health Association; American Water Works Association; Water Environment Federation (1998) Standards Methods for the Examination of Water and Wastewater, 20th ed.; American Public Health Association: Washington, D.C.

Arslan-Alaton, I.; Balcioglu, I. A.; Bahnemann, D. W. (2002) Advanced Oxidation of a Reactive Dyebath Effluent: Comparison of $\mathrm{O}_{3}, \mathrm{H}_{2} \mathrm{O}_{2} / \mathrm{UV}-\mathrm{C}$ and $\mathrm{TiO}_{2} / \mathrm{UV}-\mathrm{A}$ Processes. Water Res., 36, 1143 1154.

Bankian, G.; Mehrvar, M. (2004) Integration of Advanced Oxidation Technologies and Biological Processes: Recent Developments, Trends and Advances. J. Environ. Sci. Health A, 39 (11-12), 3029 3081.

Chen, X.; Chen, G.; Po Lock, Y. (2003) Anodic Oxidation of Dyes at Nobel Ti/B-Diamond Electrodes. Chem. Eng. Sci., 58, 9951001 .

Golob, V.; Vinder, A.; Simonic, M. (2005) Efficiency of the Coagulation/ Flocculation Method for the Treatment of Dyebath Effluents. Dyes Pigm., 67 (2), 93-97.

Gutierrez, M. C.; Pepió, M.; Crespi, M. (2002) Electrochemical Oxidation of Reactive Dyes: Method Validation and Application. Color. Technol., 118 (1), 1-5.

Jhawar, M.; Bartels, C.; Chilekar, S. (2003) UF Technology Contributes to the Recycling of Dye Salt Solutions. Filtr. Separat., 40, 20-21. 
Kim, S.; Park, C.; Kim, T. H.; Lee, J. W.; Kim, S. W. (2003) COD Reduction and Decolorization of Textile Effluent Using a Combined Process. J. Biosci. Bioeng., 95 (1), 102-105.

Kim, T. H.; Park, C.; Lee, J.; Shin, E. B.; Kim, S. (2002) Pilot Scale Treatment of Textile Wastewater by Combined Process (Fluidized Biofilm Process-Chemical Coagulation-Electrochemical Oxidation). Water Res., 36, 3979-3988.

Koch, M.; Yediler, A.; Lienert, D.; Insel, G.; Kettrup, A. (2002) Ozonation of Hydrolyzed Azo Dye Reactive Yellow 84 (CI). Chemosphere, 46, 109-113.

Koyuncu, I. (2002) Reactive Dye Removal in Dye/Salt Mixtures by Nanofiltration Membranes Containing Vinylsulphone Dyes: Effects of Feed Concentration and Cross Flow Velocity. Desalination, 143, 243-253.

Lopez-Grimau, V.; Gutierrez, M. C. (2006) Decolorisation of Simulated Reactive Dyebath Effluents by Electrochemical Oxidation Assisted by UV Light. Chemosphere, 62, 106-112.

Malik, P. K. (2004) Dye Removal from Wastewater Using Activated Carbon Developed from Sawdust: Adsorption Equilibrium and Kinetics. J. Hazard. Mater., B113, 81-88.

Metcalf \& Eddy (2003) Wastewater Engineering: Treatment and Reuse, Tchabanoglous, G., Burton, F. L., Stensel, H. D. (Eds.); McGrawHill: New York.

Mohan, N.; Balasubramanian, N.; Ahmed Basha, C. (2007) Electrochemical Oxidation of Textile Wastewater and Its Reuse. J. Hazard. Mater., B147, 644-651.
Rajkumar, D.; Guk-Kim, J. (2006) Oxidation of Various Reactive Dyes with In Situ Electro-Generated Active Chlorine for Textile Dyeing Industry Wastewater Treatment. J. Hazard. Mater., B136, $203-$ 212 .

Sakakibara, Y.; Nakayama, T. (2001) A Novel Multi-Electrode System for Electrolytic and Biological Water Treatments: Electric Charge Transfer and Application to Denitrification. Water Res., 35, 768-778.

Torrades, F.; García-Montaño, J.; García-Hortal, J. A.; Nuñez, L.; Doménech, X.; Peral, J. (2004) Decolorisation and Mineralisation of Homo- and Hetero-Bireactive Dyes Under Fenton and PhotoFenton Conditions. Color. Technol., 120, 188-194.

U.S. Environmental Protection Agency (1997) Profile of the Textile Industry, Office of Compliance Sector Notebook Project. U.S. Environmental Protection Agency: Washington, D.C., 40.

Vidal, G.; Nieto, J.; Cooman, K.; Gajardo, M.; Bornhardt, C. (2004) Unhearing Effluents Treated by an Activated Sludge System. J. Hazard. Mater., B112, 143-149.

Vilaseca, M. (2001) Microscopic Observation of Activated Sludge in Biological Treatment Plants (in Spanish). Boletín INTEXTER (UPC), 119, 67-73

Zhao, W.; Shi, H.; Wang, D. (2004) Ozonation of Cationic Red X-GRL in Aqueous Solution: Degradation and Mechanism. Chemosphere, 57, 1189-1199.

Zitrides, T. G.; Bleam, R.; Hyde, C. (2006) Using Electrolytic Respirometry to Monitor Biotreatment. Pollut. Eng., 38 (8), 3032. 